\title{
MEDICINOS DARBUOTOJŲ ŽINIOS APIE RANKŲ HIGIENOS REIKALAVIMŲ LAIKYMĄSI ASMENS SVEIKATOS PRIEŽIŪROS ISTAIGOSE
}

\author{
Miglė Lamanauskaité ${ }^{1}$, Jonas Kairys ${ }^{1,2}$, Renata Šturienè ${ }^{1}$ \\ ${ }^{1}$ Vilniaus miesto Šeškinès poliklinika, ${ }^{2}$ Vilniaus universiteto Medicinos fakultetas
}

Raktažodžiai: hospitalinès infekcijos, hospitalinių infekcijų rizikos veiksniai, rankų higiena, infekcijų kontrolès priemonès.

\begin{abstract}
Santrauka
Tyrimo tikslas - įvertinti medicinos darbuotojų žinias apie hospitalines infekcijas ir rankų higieną tarp Všt Šeškinès poliklinikos medicinos darbuotojų. Buvo atlikta medicinos darbuotojų anketinè apklausa. Respondentų buvo klausiama apie hospitalines infekcijas, priežastis, rizikos veiksnius, rankų higieną bei metodus. Išdalintos 305 anketos, grąžintos 255 anketos (atsako dažnis 83,6 proc.). Galutinei duomenų analizei panaudotos 245 anketos (96,1 proc.).

69,0 proc. respondentų teisingai apibrèžè hospitalines infekcijas. Respondentai, kurių amžius iki 40 m., su 1,91 karto didesniu šansu teisingai suprato hospitalines infekcijas, nei respondentai, kuriu amžius daugiau nei $41 \mathrm{~m}$. Respondentai, kurių amžius iki 40 m., su 3,26 karto didesniu šansu geriau žinojo apie hospitalinių infekcijų sukėlẻjų plitimo kelius, nei respondentai vyresni nei $41 \mathrm{~m}$. amžiaus. 20 proc. tiriamųjų nurodè, kad hospitalinių infekcijų sukèlëjai neplinta per rankas. 64,5 proc. respondentų nurodè, kad jų žinios apie hospitalines infekcijas pakankamos. Nustatyta, kad kuo didesnè darbo patirtis, tuo respondentas turi mažiau žinių apie hospitalines infekcijas $(r=-0,190 ; p=0,003)$. Daugumos medicinos darbuotojų žinios atitinka rankų higienos reikalavimus. 41,2 proc. respondentų nurodè, kad medicinos darbuotojai kartais neatlieka rankų higienos dèl naudojamų odą dirginančių priemonių, 21,2 proc. respondentų - dèl itempto darbo grafiko. Tyrimo metu nustatyta, kad bendrosios praktikos gydytojai su 2,46 karto didesniu šansu nurodo, kad pagrindinè rankų higienos neatlikimo priežastis yra ịtemptas darbo grafikas, lyginant su kitų sričių medicinos darbuotojais.
\end{abstract}

\section{Ivadas}

Rankų higiena - svarbiausia infekcijų prevencijos priemonè asmens sveikatos priežiūros įstaigose. Mikrobinè tarša, bakterijų kiekis ant personalo rankų svyruoja nuo 3,9 x 104 iki 4,6 x $106 \mathrm{KFV}$ (kolonijų formuojantis vienetas) [1]. Iki 35 proc. hospitalinių infekcijų (toliau - HI) išplinta dèl neteisingos rankų higienos. HI dažniausiai sukelia Staphylococcus aureus, Klebsiella spp., Escherichia coli, Enterococcus spp., Acinetobacter spp., Pseudomonas aeruginosa ir Proteus spp. Darbuotojai šiais patogenais gali susiteršti rankas ar pirštines, prisiliesdami prie įvairių aplinkos objektų (pvz., spintelių rankenèlès, pacientų oda). Patogenai gali ịsikurti prie kriauklès, ant vandens reguliavimo rankenèlių, muilo dozatoriaus ir kt. [2]. Užsienio autorių atlikti tyrimai atskleidè, kad personalo rankų ir žiedų užterštumas sieke iki 73 proc. atvejų, dažniausiai stafilokoku (23 proc.) ir grybeliu (28 proc.) [3]. Liečiant su paciento aplinka susijusius paviršius rankų ir pirštinių užterštumas siekẻ 52 proc., o liečiant pacientą - 70 proc. atvejų [4]. 94 proc. atvejų mobiliujų telefonų paviršiai buvo užteršti įvairiais mikroorganizmais, 52 proc. atvejų nustatytas Staphylococcus aureus sukèlëjas, iš jų 38 proc. atvejų atsparus meticilinui [5]

Pagrindiniai rankų higienos gydymo ịstaigose būdai yra rankų plovimas, higieninè rankų antiseptika ir chirurginé rankų antiseptika [6,7]. Rankų plovimas ir higieninė antiseptika atliekama pagal atitinkamą techniką, t. y. turi būti atliekami tam tikri judesiai, kurių metu muilas ar antiseptikas patenka ị visas plaštakų ir riešų zonas bei užtikrinamas teršalų ir mikroorganizmų pašalinimas $[8,9]$. Tyrimai rodo, kad rankų antiseptika yra veiksmingesnè nei rankų plovimas su muilu, nes antiseptikos metu pašalinama laikinoji mikroflora ir greičiau bei paprasčiau atliekama, nereikia vandens, praustuvo, trunka apie 30 sek., naudojamos priemonès mažiau dirgina odą $[6,10,11]$. Tačiau tam, kad antiseptika būtų veiksminga, būtina kokybiškai ịtrinti rankas antiseptiku $[12,13]$.

Tinkami rankų higienos bei saugos kontrolès pokyčiai 
leistų sumažinti HI plitimą ir taptų patikimu „,superbakterijų“ bei gyventojų sergamumo ịvairiomis užkrečiamosiomis ligomis mažejjimo garantu [14]. Svarbus veiksnys siekiant sumažinti mikrobinès taršos perdavimą yra praktinis personalo rankų higienos ịūdžių mokymas [15]. Tinkamos rankų higienos praktikos igyvendinimas išlieka priklausomas nuo pusiausvyros tarp naudos (įrodymais pagrista rankų higienos įtaka HI prevencijoje) ir egzistuojančių kliūčių (personalo suvokimas ir elgesys) [16].

Tyrimo tikslas - įvertinti medicinos darbuotojų žinias apie hospitalines infekcijas ir rankų higieną tarp Všș Š eškinès poliklinikos medicinos darbuotojų.

\section{Tyrimo medžiaga ir metodai}

Siekiant ịvertinti medicinos darbuotojų žinias apie hospitalines infekcijas ir rankų higieną, 2017.03-2017.04 metais Poliklinikoje atliktas momentinis (paplitimo) tyrimas. Tyrimo metodas - anketinė apklausa. Anketą sudaré dokumentiné ir specialioji dalis. Dokumentineje dalyje pateikti klausimai apie darbuotojų lytį, amžių, pareigas ir darbo stažą. Specialioje dalyje pateikti klausimai apie hospitalines infekcijas, rankų higieną ir metodus. Tiriamujų grupę sudarẻ Všs̨ Šeškinès poliklinikos (toliau - Poliklinika) vienuolikos skyrių darbuotojai, kurie buvo atrinkti atsitiktinès atrankos būdu. Išdalintos 305 anketos, grąžintos 255 anketos (atsako dažnis 83,6 proc.). Galutinei duomenų analizei panaudotos 245 anketos ( 96,1 proc.). Statistiniam duomenų apdorojimui naudojama SPSS 17.0 versija bei WinPepi, OpenEpi kompiuterinės programos. Skirtumui tarp grupių ịvertinti taikytas Pirsono (Pearson) chi kvadrato testas, Fišerio (Fisher) tikslusis metodas. Rodiklių skirtumai buvo laikomi statistiškai reikšmingais, kai $p<0,05$. Tolydiesiems kintamiesiems buvo naudojami standartiniai aprašomosios statistiskos rodikliai: mediana, minimali bei maksimali reikšmè. Kategorinių duomenų ryšio analizei buvo skaičiuojamas šansų santykis (OR). Ranginių kintamujų sąsajoms nustatyti naudota Spirmeno (Spearman) koreliacija. Anketos rezultatai pateikiami diagramose ir lentelèse.

\section{Rezultatai}

Tyrime dalyvavo 245 Poliklinikos medicinos darbuotojai. Iš jų 91,8 proc. $(\mathrm{n}=225)$ moterų ir 8,2 proc. $(\mathrm{n}=20)$ vyrų. Vidutinis respondentų amžius buvo $53 \mathrm{~m}$. (min -24 metų, $\max -68$ metų). 49 proc. $(n=120)$ tiriamujų turèjo aukštaji išsilavinimą, 33,9 proc. $(\mathrm{n}=83)$ - aukštesniji išsilavinimą, 13,5 proc. $(\mathrm{n}=33)$ - aukštajj neuniversitetinį išsilavinimą. Dauguma tyrime dalyvavusių respondentų buvo bendrosios praktikos slaugytojos (42,9 proc., $\mathrm{n}=105)$, kiek mažiau gydytojų specialistų ( 25,3 proc., $n=62) .44,9$ proc. $(n=110)$ tiriamujų darbo patirtis buvo daugiau nei 21 metai.

69,0 proc. $(\mathrm{n}=169)$ respondentų turejjo teisingą suvokimą apie HI. Vertinant respondentų subjektyvią nuomonę apie HI pagal amžiaus grupes, nustatyta, kad 75 proc. $(n=15)$ iki 30 m. amžiaus tiriamujų teisingai apibrèžè HI sąvoką, o 25 proc. $(\mathrm{n}=5)$ šios amžiaus grupès respondentų nurodè klaidingą $\mathrm{HI}$ apibrèžimą $\left(\chi^{2}=18,50 ; p=0,03\right) .62,2$ proc. $(n=23)$ vyresnių nei $61 \mathrm{~m}$. tiriamujų turèjo teisingą supratimą apie HI, o 37,8 proc. $(\mathrm{n}=14)$ - klaidingą. Respondentai, kurių amžius iki 40 m., su 1,91 karto didesniu šansu turejjo teisingą suvokimą apie HI, nei respondentai, kurių amžius daugiau nei $41 \mathrm{~m}$. (OR=1,94; PI 95\%: 1,91-4,15; $\mathrm{p}=0,04)$.

35,5 proc. $(n=87)$ respondentų teisingai atsakè ị klausimą apie HI sukėlejjų plitimo kelius. 20 proc. $(n=49)$ tiriamujų nurodè, kad HI sukèlejai neplinta per rankas. Vertinant pagal amžių, 6,7 proc. $(\mathrm{n}=2) 31-40 \mathrm{~m}$. amžiaus ir 21,6 proc. $(\mathrm{n}=21)$ 51-60 m. amžiaus respondentų nurodè, kad HI sukèlèjai neplinta per personalo rankas $\left(\chi^{2}=34,12 ; \mathrm{p}=0,02\right)$. Respondentai, kurių amžius iki 40 m., su 3,26 karto didesniu šansu geriau žinojo apie HI sukèlèjų plitimo kelius, nei respondentai vyresni nei $41 \mathrm{~m}$. amžiaus $(\mathrm{OR}=3,26$; PI 95\%: $1,72-6,18 ; \mathrm{p}<0,001)$. Nei vienas respondentas, kurio darbo patirtis mažiau nei 1 metai, nenurodè, kad HI sukèlëjai neplinta per rankas, tuo tarpu net 27,5 proc. $(n=14)$ respondentu, kurių darbo patirtis 16-20 m., nurode, kad HI neplinta per personalo rankas $\left(\chi^{2}=50,64 ; p=0,002\right)$. Tyrimo metu nustatyta, kad respondentai, kurių darbo patirtis iki $10 \mathrm{~m}$., su 2,57 karto didesniu šansu turi teisingesnị supratimą apie HI sukèlejjų plitimo kelius, nei respondentai, kurių darbo patirtis daugiau nei $11 \mathrm{~m}$. (OR=2,57; PI 95\%: 1,41-4,68; $\mathrm{p}<0,001)$. 64,5 proc. $(n=158)$ respondentų nurodè, kad jų žinios apie HI yra pakankamos, o 6,1 proc. $(n=15)$ - nepakankamos. Atlikus Spirmeno (Spearman) koreliaciją, vertinant ryšį tarp respondentų darbo patirties bei tarp subjektyvios jų nuomonès, ar turi pakankamai žinių apie HI, nustatyta, kad kuo didesnè darbo patirtis, tuo respondentas turi mažiau žinių apie HI $(r=-0,190 ; p=0,003)$.

Tyrimo metu, vertinant respondentų žinias apie rankų higieną, buvo pateikti 7 teiginiai, $\mathfrak{i}$ kuriuos respondentai galejjo atsakyti teigiamai, neigiamai ar nurodyti, kad nežino (1 paveikslas). İ I teiginị teisingai atsakè 47,8 proc. $(n=117)$ respondentų, i II teigini -51 proc. $(\mathrm{n}=125)$ tiriamujų, i III teiginį teisingai atsake 23,3 proc. $(n=57)$ respondentų, į IV teigini $-25,7$ proc. $(n=63)$ respondentu, i $\mathrm{V}$ teigini $-61,6$ proc. $(n=151)$ respondentu, i VI teigini $-7,3$ proc. $(n=18)$ respondentų, i VII teigini - 76,7 proc. $(\mathrm{n}=188)$ respondentų.

Vertinant respondentų žinias, kada reikia atlikti rankų plovimą ir/ar higieninę rankų antiseptiką, jiems buvo užduodami klausimai apie rankų higienos metodus. 22,4 proc. $(n=55)$ respondentų nurodè, kad po auskultacijos procedūros 


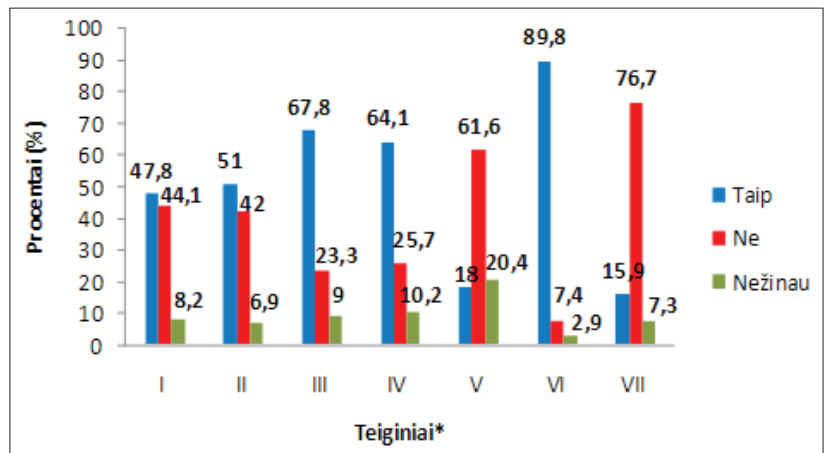

1 paveikslas. Respondentų žinios apie rankų higieną (procentais) I teiginys. Alkoholinis ranku antiseptikas efektyviau užmuša ir pašalina laikinus mikroorganizmus nei ranku plovimas muilu.

II teiginys. Ranku ịtrinimas antiseptiku yra greitesnè ir paprastesné procedūra nei ranku plovimas.

III teiginys. Ranku itrinimas antiseptikais labiau dirgina oda nei ranku plovimas. IV teiginys. Ranku plovimas yra labiau tausojanti rankas procedūra nei antiseptiko naudojimas.

V teiginys. Antiseptiko apsauginis poveikis stipresnis, jei medicininès pirštinès užsimaunamos ant šiek tiek drègnu ranku.

VI teiginys. Valant/dezinfekuojant aplinkos daiktus būtina mūvèti medicinines pirštines. VII teiginys. Medicinines pirštines bütina mūvèti matuojant paciento pulsa ar kraujospūdil.

reikia atlikti tik higieninę rankų antiseptiką (IB) ${ }^{1}$, net 62 proc. $(\mathrm{n}=152)$ respondentų nurodè, kad po tokios procedūros reikia atlikti tik rankų plovimą (2 paveikslas). 49,8 proc. $(n=122)$ tiriamujų nurodé, kad prieš užsimaunant medicinines pirštines reikia atlikti tik rankų plovimą, tik 11 proc. $(n=27)$ respondentų nurodè, kad reikia atlikti tik rankų antiseptiką (IB). 85,3 proc. $(n=209)$ respondentų nurodè, kad po sąlyčio su užterštais paviršiais reikia rankas nusiplauti ir ịtrinti antiseptiku. Tik 8,2 proc. ( $\mathrm{n}=20$ ) tiriamujų nurodé, kad po sąlyčio su užterštais daiktais reikia atlikti tik rankų antiseptiką (IB). 86,9 proc. $(\mathrm{n}=213$ ) respondentų teisingai atsakè, kad nusimovus paciento krauju užterštas pirštines reikia rankas nusiplauti, o po to atlikti higieninę ranku antiseptiką (IA).

25,4 proc. $(n=16)$ respondentu, kurie dirbo gydytojais specialistais, nurodè, kad po auskultacijos reikia atlikti tik higieninę rankų antiseptiką, tuo tarpu 74,1 proc. $(\mathrm{n}=20)$ respondentu, kurie dirbo bendrosios praktikos gydytojais (toliau - BPG), nurodè, kad po auskultacijos reikia rankas tik nusiplauti (1 lentelè). Respondentai, kurių darbo patirtis iki $11 \mathrm{~m}$. su 2,28 karto didesniu šansu žino, kaip teisingai elgtis po auskultacijos (OR=2,28; PI 95\%: 1,22-4,26; $\mathrm{p}=0,005)$.

\footnotetext{
${ }^{1}$ Ranking system for evidence: category IA, strongly recommended for implementation and strongly supported by welldesigned experimental, clinical, or epidemiological studies;

category IB, strongly recommended for implementation and supported by some experimental, clinical, or epidemiological studies and a strong theoretical rationale. category IC, Required for implementation, as mandated by federal and/or state regulation or standard.

category II, Suggested for implementation and supported by suggestive clinical or epidemiologicalstudies or a theoretical rationale or a consensus by a panel of experts
}

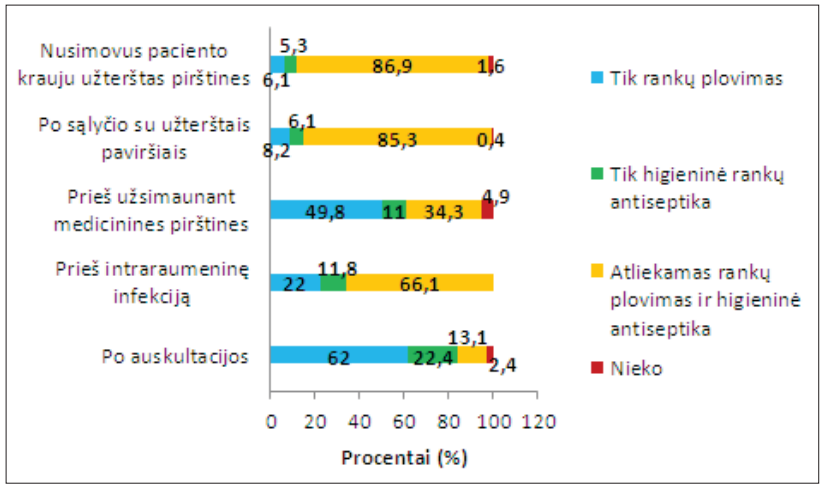

2 paveikslas. Respondentų žinios apie rankų higienos metodo pasirinkimą (procentais)

Tik 12,7 proc. $(\mathrm{n}=8)$ respondentu, kurie dirbo gydytojais specialistais, ir 13,3 proc. $(\mathrm{n}=14)$ respondentu, kurie dirbo bendrosios praktikos slaugytojomis (toliau - BPS), nurodè, kad prieš užsimaunant medicinines pirštines reikia atlikti tik higieninę rankų antiseptiką.

41,2 proc. $(\mathrm{n}=101)$ respondentų nurodè, kad pagrindinis trukdantis veiksnys atlikti rankų higieną - naudojamos odą dirginančios priemonès, o 21,2 proc. $(\mathrm{n}=52)$ respondentų nurode, kad ittemptas darbo grafikas. 50,8 proc. $(\mathrm{n}=32)$ tiriamujjų, kurie dirbo gydytojais specialistais, ir 40 proc. $(n=42)$ respondentų, kurie dirbo BPS, nurodè, kad medicinos darbuotojai neatlieka rankų higienos, nes naudojamos odą dirginančios priemonès. Tuo tarpu 37 proc. $(n=10)$ respondentu, kurie dirbo BPG, nurodè, kad dèl įtempto darbo grafiko, o 25,9 proc. $(n=7)$ BPG teigè, kad pirštinių mūvèjimas leidžia neatlikti ranku higienos $\left(\chi^{2}=51,48 ; p=0,001\right)$. Tyrimo metu nustatyta, kad BPG, su 2,46 karto didesniu šansu nurodo, kad pagrindinè rankų higienos neatlikimo priežastis buvo ịtemptas darbo grafikas, lyginant su kitų sričių medicinos darbuotojais $(\mathrm{OR}=2,46$; PI 95\%: 1,11-5,77; $\mathrm{p}=0,02)$.

50 proc. $(\mathrm{n}=15)$ respondentų, kurių darbo patirtis $1-5$ m., nurodé, kad medicinos darbuotojai neatlieka rankų higienos, nes naudojamos odą dirginančios priemonès, o 26,7 proc. $(\mathrm{n}=8)$ respondentų, nurodè, kad dèl ịtempto darbo grafiko. Respondentai, kurių darbo patirtis daugiau nei $21 \mathrm{~m}$. ir daugiau, nurodè, kad pagrindinès priežastys, dẻl kurių neatliekama rankų higiena - naudojamos odą dirginančios priemonès $(35,5$ proc.; $n=39)$ ir ittemptas darbo grafikas $(24,5$ proc.; $\mathrm{n}=27),\left(\chi^{2}=57 ; \mathrm{p}=0,04\right)$.

42,9 proc. $(\mathrm{n}=105)$ respondentų teigè, kad jų rankų oda sveika. 53,3 proc. $(\mathrm{n}=16)$ respondentų, kurių darbo patirtis 1-5 m., nurodè, kad jų rankų oda sveika. Tuo tarpu 60 proc. $(\mathrm{n}=66)$ respondentų, kurių darbo patirtis daugiau nei $21 \mathrm{~m}$., nurodè, kad jų rankų oda pažeista $\left(\chi^{2}=29,62 ; p=0,03\right) .62$ proc. $(n=152)$ respondentų nurodè, kad labiausiai dirgina 
rankų odą naudojami antisepti- 1 lentelẻ. Respondentų žinios apie rankų higieną, atsižvelgiant ị respondentų darbo patirtí, prokai ir tik 7,8 proc. $(\mathrm{n}=19)$ respon- fesiją, išsilavinimą

dentų nurodè, kad muilas.

\section{Rezultatu aptarimas}

2015 m. LSMUL Kauno klinikų atliktame tyrime nustatyta, kad mažiau kaip du trečdaliai slaugytojų žinojo tikslų HI apibrèžimą, kurị dažniau pasirinko operacinių slaugytojos [17]. 2007 $\mathrm{m}$. R. Monkevičienès atlikto tyrimo rezultatai parodé, kad mažiau kaip pusė apklaustuju žinojo HI apibrèžimą ir didžioji dalis teige, kad HI nustatomos tik pacientams [18], o 2013 m., R. Perednienès tyrimo duomenimis, beveik ketvirtadalis slaugytojuc manè, kad HI sukeliamos gydymo įstaigoje cirkuliuojančių mikroorganizmų [19]. Mūsų tyrimo metu nustatyta, kad 69,0 proc. $(\mathrm{n}=169)$ respondentų turèjo teisingą suvokimą apie HI. 39,7 proc. $(\mathrm{n}=25)$ respondentu, kurie dirbo gydytojais specialistais, ir 29,9 proc. $(n=7)$ respondentu, kurie dirbo BPS, nurodè, teisingą HI apibrèžimą $\left(\chi^{2}=28,42\right.$; $\mathrm{p}=0,02)$. Nustatyta, kad respondentai, kurių amžius iki 40 m., su 1,91 karto didesniu šansu teisingai supranta HI, nei respondentai, kurių amžius daugiau nei $41 \mathrm{~m}$. $(\mathrm{OR}=1,94$; PI 95\%: 1,91-4,15; $\mathrm{p}=0,04)$. Mūsų tyrimo metu 35,5 proc. $(\mathrm{n}=87)$ respondentu teisingai atsakè i klausimą apie $\mathrm{HI}$ sukèlejų plitimo kelius. Net 20 proc. $(n=49)$ tiriamujų nurodè, kad HI sukèlëjai neplinta per rankas. $2015 \mathrm{~m}$. tyrimo duomenimis, kaip pagrindinius HI sukèlejų patekimo kelius nurodè personalo rankas (97,8 proc.) ir netinkamą instrumentų dezinfekciją ir (ar) sterilizaciją ( 98,9 proc.). Panašūs duomenys gauti ir kituose tyrimuose $[6,20]$. Užsienio tyrimu

\begin{tabular}{|c|c|c|c|c|c|c|c|c|c|}
\hline \multicolumn{4}{|c|}{ Teiginiai/kintamieji } & $\begin{array}{l}\text { Tik rankų } \\
\text { plovimas }\end{array}$ & $\begin{array}{l}\text { Tik higie- } \\
\text { ninè rankų } \\
\text { antiseptika }\end{array}$ & $\begin{array}{l}\text { Atliekamas rankų } \\
\text { plovimas + rankų } \\
\text { antiseptika }\end{array}$ & Nieko & $\chi^{2}$ & $\mathbf{p}$ \\
\hline \multirow{20}{*}{ 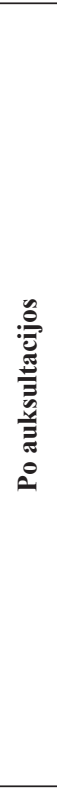 } & \multirow{12}{*}{ 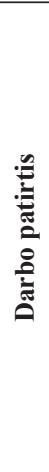 } & \multirow[t]{2}{*}{$<1 \mathrm{~m}}$. & $\mathbf{N}$ & 2 & 0 & 0 & 0 & \multirow[t]{12}{*}{27,37} & \multirow[t]{12}{*}{0,026} \\
\hline & & & $\%$ & 100 & 0 & 0 & 0 & & \\
\hline & & \multirow[t]{2}{*}{$1-5 \mathrm{~m}}$. & $\mathbf{N}$ & 16 & 9 & 5 & 0 & & \\
\hline & & & $\%$ & 53,3 & 30 & 16,7 & 0 & & \\
\hline & & \multirow[t]{2}{*}{ 6-10 m. } & $\mathbf{N}$ & 7 & 12 & 7 & 1 & & \\
\hline & & & $\%$ & 25,9 & 44,4 & 25,9 & 3,7 & & \\
\hline & & \multirow[t]{2}{*}{$11-15 \mathrm{~m}}$. & $\mathbf{N}$ & 14 & 7 & 4 & 0 & & \\
\hline & & & $\%$ & 56 & 28 & 10 & 0 & & \\
\hline & & \multirow[t]{2}{*}{$16-20 \mathrm{~m}}$. & $\mathbf{N}$ & 36 & 11 & 3 & 1 & & \\
\hline & & & $\%$ & 70,6 & 21,6 & 5,9 & 2 & & \\
\hline & & \multirow[t]{2}{*}{$>21 \mathrm{~m}$} & $\mathbf{N}$ & 77 & 16 & 13 & 4 & & \\
\hline & & & $\%$ & 70 & 14,51 & 11,8 & 3,6 & & \\
\hline & \multirow{8}{*}{ 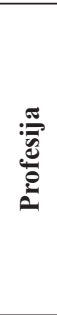 } & \multirow{2}{*}{\begin{tabular}{|l|} 
Gydytojas \\
specialistas
\end{tabular}} & $\mathbf{N}$ & 42 & 16 & 3 & 2 & \multirow[t]{8}{*}{23,65} & \multirow[t]{8}{*}{0,005} \\
\hline & & & $\%$ & 66,7 & 25,4 & 4,8 & 3,2 & & \\
\hline & & \multirow[t]{2}{*}{ BPG } & $\mathbf{N}$ & 20 & 0 & 4 & 3 & & \\
\hline & & & $\%$ & 74,1 & 0 & 14,8 & 11,1 & & \\
\hline & & \multirow[t]{2}{*}{ BPS } & $\mathbf{N}$ & 62 & 26 & 17 & 0 & & \\
\hline & & & $\%$ & 59 & 24,8 & 46,2 & 0 & & \\
\hline & & \multirow[t]{2}{*}{ Kita } & $\mathbf{N}$ & 28 & 13 & 8 & 1 & & \\
\hline & & & $\%$ & 56 & 26 & 16 & 2 & & \\
\hline \multirow{20}{*}{ 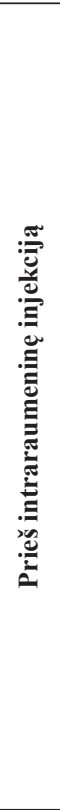 } & \multirow{12}{*}{ 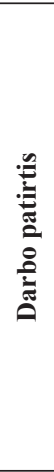 } & \multirow[t]{2}{*}{$<1 \mathrm{~m}}$. & $\mathbf{N}$ & 0 & 0 & 2 & 0 & \multirow{12}{*}{25,45} & \multirow[t]{12}{*}{0,005} \\
\hline & & & $\%$ & 0 & 0 & 100 & 0 & & \\
\hline & & \multirow[t]{2}{*}{$1-5 \mathrm{~m}}$. & $\mathbf{N}$ & 1 & 6 & 23 & 0 & & \\
\hline & & & $\%$ & 3,3 & 20 & 76,7 & 0 & & \\
\hline & & 6-10 m. & $\mathbf{N}$ & 2 & 3 & 22 & 0 & & \\
\hline & & & $\%$ & 7,4 & 11,1 & 81,5 & 0 & & \\
\hline & & $11-15 \mathrm{~m}$. & $\mathbf{N}$ & 1 & 3 & 21 & 0 & & \\
\hline & & & $\%$ & 4 & 12 & 84 & 0 & & \\
\hline & & $16-20 \mathrm{~m}$. & $\mathbf{N}$ & 13 & 6 & 32 & 0 & & \\
\hline & & & $\%$ & 25,5 & 11,8 & 62,7 & 0 & & \\
\hline & & $>21 \mathrm{~m}$. & $\mathbf{N}$ & 37 & 11 & 62 & 0 & & \\
\hline & & & $\%$ & 33,6 & 10 & 56,4 & 0 & & \\
\hline & & Aukštasis & $\mathbf{N}$ & 22 & 19 & 79 & 0 & 14,67 & 0,023 \\
\hline & & & $\%$ & 18,3 & 15,8 & 65,8 & 0 & & \\
\hline & $\tilde{\Xi}$ & Aukštasis & $\mathbf{N}$ & 6 & 3 & 24 & 0 & & \\
\hline & 音 & $\begin{array}{l}\text { neuniver- } \\
\text { sitetinis }\end{array}$ & $\%$ & 18,2 & 9,1 & 72,7 & 0 & & \\
\hline & $\frac{\pi}{\overline{7}}$ & \begin{tabular}{|l|} 
Aukštes- \\
\end{tabular} & $\mathbf{N}$ & 20 & 7 & 56 & 0 & & \\
\hline & & nysis & $\%$ & 24,1 & 8,4 & 67,5 & 0 & & \\
\hline & & Kita & $\mathbf{N}$ & 6 & 0 & 3 & 0 & & \\
\hline & & & $\%$ & 66,7 & 0 & 33,3 & 0 & & \\
\hline
\end{tabular}

Lentelès tęsinys kitame puslapyje.

duomenimis, personalo rankos ir nešiojami papuošalai dažnai yra užteršti HI sukẻlëjais [21]. N. Gilboy, P. K. Howard ir kitų autorių atlikti tyrimai rodo, kad bakterijų rezervuarai yra ilgi nagai, įskilęs nagų lakas, žiedai, apyrankès, laikrodžiai [22-24].

Dèl personalo kontakto su pacientu ir jo aplinka (per personalo rankas, pirštines, aprangą) didejja kryžminès infekcijos perdavimo rizika [25]. Taip pat personalas nurodo- 


\section{8}

mas kaip potencialus infekcijos rezervuaras, jei serga ūmiomis infekcijomis ar turi pūlingas odos infekcijas, nosiaryklès kolonizaciją meticilinui atspariu auksiniu stafilokoku [26]. Gydymo įstaigos aplinkoje $S$. aureus plisti ypač didelę reikšmę turi medicinos darbuotojų ranku žaizdos, jų išskyros, todèl pagrindinis prevencijos elementas - tinkama rankų higiena [27, 28]. Didesnè tikimybė rankų kolonizacijos bakterijomis ir grybeliais, net ir atlikus tinkamą rankų antiseptiką, išlieka tarp personalo su dirbtiniais (priklijuojamais) ar lakuotais nagais [29, 30]. Mūsų tyrimo metu, vertinant respondentų žinias apie rankų higieną, buvo pateikti 7 teiginiai, i kuriuos respondentai galejo atsakyti teigiamai, neigiamai ar nurodyti, kad nežino. 47,8 proc. respondentų teisingai nurodè, kad alkoholinis rankų antiseptikas efektyviau užmuša ir pašalina laikinus mikroorganizmus nei rankų plovimas muilu. Tik 25,7 proc. tiriamujų teisingai atsaké, kad rankų plovimas nėra labiau tausojanti rankas procedūra nei antiseptiko naudojimas. 22,4 proc. $(n=55)$ respondentu nurodè, kad po auskultacijos procedūros reikia atlikti tik higieninę rankų antiseptiką, Baltijos regiono atsparumo antibiotikams tinklo - BARN (angl. Baltic antibiotic resistance collaborative network) $2011 \mathrm{~m}$. atlikto tyrimo duomenimis, nustatyta, kad medicinos darbuotojų žinios apie rankų higieną nèra pakankamos. Pavyzdžiui, kad svarbiausia priemone infekcijoms valdyti - rankų higiena nurode tik 12,7 proc. medicinos personalo [31]. Dauguma gydy-

\begin{tabular}{|c|c|c|c|c|c|c|c|c|c|}
\hline \multirow{8}{*}{ 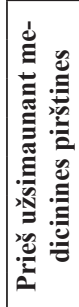 } & \multirow{8}{*}{ 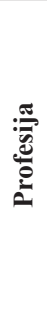 } & \multirow{2}{*}{$\begin{array}{l}\text { Gydytojas } \\
\text { specialistas }\end{array}$} & $\mathbf{N}$ & 23 & 8 & 28 & 4 & \multirow[t]{8}{*}{19,71} & \multirow[t]{8}{*}{0,020} \\
\hline & & & $\%$ & 36,5 & 12,7 & 44,4 & 6,3 & & \\
\hline & & \multirow[t]{2}{*}{ BPG } & $\mathbf{N}$ & 14 & 2 & 11 & 0 & & \\
\hline & & & $\%$ & 51,9 & 7,4 & 40,7 & 0 & & \\
\hline & & \multirow[t]{2}{*}{ BPS } & $\mathbf{N}$ & 49 & 14 & 34 & 8 & & \\
\hline & & & $\%$ & 46,7 & 13,3 & 32,4 & 7,6 & & \\
\hline & & \multirow[t]{2}{*}{ Kita } & $\mathbf{N}$ & 36 & 3 & 11 & 0 & & \\
\hline & & & $\%$ & 72 & 6 & 22 & 0 & & \\
\hline \multirow{8}{*}{ 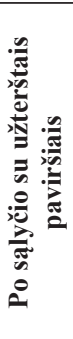 } & \multirow{8}{*}{ 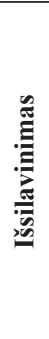 } & \multirow[t]{2}{*}{ Aukštasis } & $\mathbf{N}$ & 6 & 7 & 106 & 1 & \multirow[t]{8}{*}{24,36} & \multirow[t]{8}{*}{0,004} \\
\hline & & & $\%$ & 5 & 5,8 & 88,3 & 0,8 & & \\
\hline & & \multirow{2}{*}{$\begin{array}{l}\text { Aukštasis } \\
\text { neuniver- } \\
\text { sitetinis }\end{array}$} & $\mathbf{N}$ & 3 & 5 & 25 & 0 & & \\
\hline & & & $\%$ & 9,1 & 15,2 & 75,8 & 0 & & \\
\hline & & \multirow{2}{*}{$\begin{array}{l}\text { Aukštes- } \\
\text { nysis }\end{array}$} & $\mathbf{N}$ & 7 & 3 & 73 & 0 & & \\
\hline & & & $\%$ & 8,4 & 3,6 & 88 & 0 & & \\
\hline & & \multirow[t]{2}{*}{ Kita } & $\mathbf{N}$ & 4 & 0 & 5 & 0 & & \\
\hline & & & $\%$ & 44,4 & 0 & 55,6 & 0 & & \\
\hline
\end{tabular}

tojų ir slaugytojų supranta, kad tinkama rankų higiena gali padèti išvengti hospitalinių infekcijų, tačiau dažniau rankos plaunamos po kontakto su pacientu, jo kūno skysčiais nei prieš tiesioginị kontaktą su pacientu [32]. Daug atsakingesnis rankų higienos elgesys pastebimas tarp slaugytojų nei gydytojų [32, 33].

Mūsų tyrimo metu nustatyta, kad 41,2 proc. (n=101) respondentų kaip pagrindinį trukdantị veiksnį atlikti rankų higieną įvardijo naudojamas odą dirginančias priemones, 21,2 proc. $(\mathrm{n}=52)$ respondentų nurode, kad įtemptas darbo grafikas. Tyrimo metu nustatyta, kad BPG su 2,46 karto didesniu šansu nurodo, kad pagrindinè rankų higienos neatlikimo priežastis yra įtemptas darbo grafikas, lyginant su kitų sričių medicinos darbuotojais $(\mathrm{OR}=2,46$; PI 95\%: 1,11-5,77; $\mathrm{p}=0,02) .2012 \mathrm{~m}$. atlikto tyrimo duomenimis, 39,5 proc. atsakiusių respondentų nurodè, jog labiausiai tinkamai atlikti rankų higieną trukdo naudojamos odą dirginančios priemonès. Antras pagal dažnumą veiksnys, trukdantis tinkamai rankų higienai, buvo pirštinių mūvejjimas (21 proc.). İvertinus respondentų nuomonę apie veiksnius, kurie labiausiai trukdo atlikti rankų higieną, priklausomai nuo jų užimamų pareigų, nustatyta kad darbuotojams, kurių darbo stažas trumpesnis nei treji metai, labiausiai rankų higieną atlikti trukdo naudojamos dirginančios odą priemonès (46,8 proc.) bei įtemptas darbo grafikas (16,1 proc.). Respondentams, kurių darbo stažas 3-7 metai, taip pat labiausia trukdo naudojamos dirginančios odą priemonès bei įtemptas darbo grafikas (29,6 proc.). Ilgiau nei septynerius metus dirbantiesiems prie ranku higienai trukdančių naudojamų odą dirginančių priemonių taip pat prisideda ir pirštinių mūvejjimas (atitinkamai 38,2 proc. ir 25 proc.) [34]. Mūsų tyrimo duomenimis, 50 proc. $(\mathrm{n}=15)$ respondentų, kurių darbo patirtis 1-5 m., nurodè, kad medicinos darbuotojai neatlieka rankų higienos, nes naudojamos odą dirginančios priemonès, o 26,7 proc. $(n=8)$ respondentų nurodè, kad dèl įtempto darbo grafiko. Respondentai, kurių darbo patirtis daugiau nei $21 \mathrm{~m}$. ir daugiau, nurodè, kad pagrindinès priežastys, dẻl kurių neatliekama rankų higiena - naudojamos odą dirginančios priemonès $(35,5$ proc.; $n=39)$ ir itemptas darbo grafikas $(24,5$ proc.; $n=27),\left(\chi^{2}=57 ; p=0,04\right)$. Tyrimais nustatyta, kad teorinès personalo žinios apie rankų higieną pakankamos, tačiau lyginant su praktika skiriasi (87 proc. apie rankų antiseptiką žinojo teoriškai, o praktiškai žinias taikè tik 75 proc.) [65]. Italijos tyrejjai nustatè, kad 86 proc. slaugytojų prieš intervencijas atlieka ranku antiseptika, tačiau teisingai atliko tik 55 proc. [108]. Personalo nepakankamos rankų higienos atlikimo ir (ar) vengimo priežastimis nurodomos odos sudirginimas, alerginès reakcijos dẻl dažno plovimo ir dezinfekcinių priemonių naudojimo, ribotas 
ir (ar) nepatogus prièjimas prie dezinfekcinių priemonių, didelis darbo krūvis, laiko stoka, skubejjimas, užmaršumas, žinių trūkumas, kitų kolegų netinkamo elgesio įtaka [35-37].

Mūsų tyrimo duomenimis, 42,9 proc. $(\mathrm{n}=105)$ respondentų teigè, kad jų rankų oda sveika. 62 proc. $(n=152)$ respondentų nurodè, kad labiausiai dirgina rankų odą naudojami antiseptikai ir tik 7,8 proc. $(\mathrm{n}=19)$ respondentų nurodé, kad muilas. Remiantis 1992-2002 m. publikacijų apžvalga, galima teigti, jog rankų ploviklis, turintis sudetyje alkoholio, efektyviau pašalina mikroorganizmus nuo rankų, jo naudojimas užima mažiau laiko bei rečiau sudirgina odą nei rankų plovimas muilu bei vandeniu, ar kitų antiseptinių priemonių naudojimas [34]. Dèl dažno rankų plovimo pasireiškia fiziologiniai bei mikrobiologiniai odos pokyčiai, kurie yra ta priežastis, dèl ko medicinos darbuotojai skundžiasi išsausèjusia rankų oda, jaučiamu odos deginimu, eritema, odos pleiskanojimais bei įtrūkimais. Dažnas rankų plovimas mažina paviršinių odos riebalų kiekị, dèl to naudojami plovikliai paveikia ir gilesnius odos sluoksnius. Sausuoju metų laiku bei turintiems sausą odą žmonėms šis riebalų eikvojimas vyksta dar greičiau [38]. Nustatyta, kad blogai medicinos personalo rankų higienai turi ịtakos procedūros pobūdis, laiko stoka, užmaršumas, skubotumas, žinių trūkumas [39].

\section{Išvados}

1. 69 proc. respondentų turi teisingą supratimą apie hospitalines infekcijas. Geresnị supratimą apie hospitalines infekcijas turi jaunesnio nei vyresnio amžiaus respondentai, turintys mažesnę nei didesnę darbo patirtį, aukštaji /aukštaji neuniversitetinị nei aukštesniji išsilavinimą.

2. Daugumos medicinos darbuotojų žinios atitinka rankų higienos reikalavimus. Daugiau žinių apie rankų higieną turi mažesnę nei didesnę darbo patirtị turintys respondentai.

3. Pagrindiniai veiksniai, dèl kurių medicinos darbuotojai neatlieka rankų higienos - naudojamos rankų odą dirginančios medžiagos ( 41,2 proc.) bei ittemptas darbo grafikas (21,2 proc.).

4. Bendrosios praktikos gydytojai su 2,46 karto didesniu šansu nurodo, kad pagrindinè rankų higienos neatlikimo priežastis yra ịtemptas darbo grafikas, lyginant su kitų sričiu medicinos darbuotojais (OR=2,46; PI 95\%: 1,11-5,77; $\mathrm{p}=0,02$ ).

\section{Literatūra}

1. Gierasimovič Z., Kalibatienė D., Mikaliūkštienė A. Higieninèepidemiologinè intervencinių procedūrų sauga slaugos praktikoje. Medicinos teorija ir praktika, 2016; 22(4): 322-327. https://doi.org/10.15591/mtp.2016.052

2. Axel Kramer, Ingeborg Schwebke, Günter Kamp. How long do nosocomial pathogens persist on inanimate surfaces? A systematic review. MC Infectious Diseases20066:130, DOI:
10.1186/1471-2334-6-130. Prieiga: https://bmcinfectdis.biomedcentral.com/articles/10.1186/1471-2334-6-130

3. Khodavaisy S, Nabili M, Davari B, Vahedi M. Evaluation of bacterial and fungal contamination in the health care workers' hands and rings in the intensive care unit. J Prev Med Hyg 2011;52(4):215-8.

4. Hayden MK, Blom DW, Lyle EA, Moore CG, Weinstein RA. Risk of hand or glove contamination after contact with patients colonized with vancomycin-resistant enterococcus or the colonized patients environment. Infect Control Hosp Epidemiol. 2008;29(2):149-54.

https://doi.org/10.1086/524331

5. Ulger F, Esen S, Dilek A, Yanik K, Gunaydin M, Leblebicioglu H. Are we aware how contaminated our mobile phones with nosocomial pathogens? Ann Clin Microbiol Antimicrob 2009;6;8:7

6. WHO Guidelines on Hand Hygiene in Health Care. World Health Organization, 2009. Prieiga per internetą: http://whqlibdoc. who.int/publications/2009/9789241597906_eng.pdf

7. Friedman C, Newsom SWB, editors. IFIC Basic Concepts of Infection Control. 3rd ed. Portadown: International Federation of Infection Control, 2007:65-74.

8. Lietuvos higienos norma HN 47-1:2012 "Sveikatos priežiūros ịstaigos. Infekcijų kontrolès reikalavimai", 3 priedas. Prieiga: https://www.e-tar.lt/portal/lt/legalAct/TAR.A8DBA9F5457B

9. WHO and Patient Safety. Hand hygiene technical reference manual: to be used by health-care workers, trainers and observers of hand hygiene practices. Prieiga: http://apps.who.int/iris/ bitstream/10665/44196/1/9789241598606_eng.pdf

10. Widmer AF. Replace hand washing with use of a waterless alcohol hand rub? Clin Infect Dis 2000;31:136-143. https://doi.org/10.1086/313888

11. Voss A, Widmer AF. No time for handwashing!? Handwashing versus alcoholic rub: can we afford 100\% compliance? Infect Control Hosp Epidemiol. 1997;18:205-208.

https://doi.org/10.2307/30141985

12. Aboumatar H, Ristaino P, Davis RO, Thompson CB, Maragakis L, Cosgrove S, Rosenstein B, Perl TM. Infection prevention promotion program based on the PRECEDE model: improving hand hygiene behaviors among healthcare personnel. Infection control and hospital epidemiology 2012; 33: 144-51.

https://doi.org/10.1086/663707

13. Al-Hamad A, Maxwell S. How clean is clean? Proposed methods for hospital cleaning assessment. The Journal of Hospital Infection 2008; 70: 328-34. https://doi.org/10.1016/j.jhin.2008.08.006

14. WHO publishes list of bacteria for which new antibiotics are urgently needed. Prieiga: http://www.who.int/mediacentre/ news/releases/2017/bacteria-antibiotics-needed/en/

15. Basic Concepts of Infection Control, International Federation of Infection Control, Friedman C, Newsom W., 2010.

16. Allegranzi B, Pittet D. Role of hand hygiene in healthcare associated infection prevention. J Hosp Infect 2009;73(4):305-15. 
https://doi.org/10.1016/j.jhin.2009.04.019

17. Michalkevičienė R. Chirurginio profillio slaugytojų žinių apie hospitalines infekcijas vertinimas, magistranto baigiamasis darbas / mokslinè vadovè dr. G. Vizujè; Lietuvos sveikatos mokslų universitetas, Slaugos fakultetas, Slaugos ir rūpybos katedra. - Kaunas, 2015; 86.

18. Monkevičienė R. Sveikatos apsaugos ịstaigų veiklos kokybės gerinimas sprendžiant hospitalinių infekcijų problemą: magistro tezès. Vilnius: Mykolo Romerio universitetas, 2007; 1.

19. Perednienè R. Hospitalinès infekcijos ir jų valdymo galimybès X ligoninejje: magistro tezès. Kaunas: LSMU, 2013; 12.

20. Kac G, Masmejean E, Gueneret M, Rodi A, Peyrard S, Podglajen I.Bactericidal efficacy of a $1.5 \mathrm{~min}$ surgical hand-rubbing protocol under in use conditions. J Hosp Infect 2009;72(2):135-9. https://doi.org/10.1016/j.jhin.2009.02.015

21. Khodavaisy S, Nabili M, Davari B, Vahedi M. Evaluation of bacterial and fungal contamination in the health care workers' hands and rings in the intensive care unit. J Prev Med Hyg 2011;52(4):215-8.

22. Geffers C, Sohr D, Gastmeier P. Mortality attributable to hospital acquired infections among surgical patients. Infection Control and Hospital Epidemiology, 2008; 29: 1167-70. https://doi.org/10.1086/592410

23. Gilboy N, Howard P. Compliance with Hand Hygiene Guidelines. Advanced Emergency Nursing Journal 2008; 30(30): 193-200. https://doi.org/10.1097/01.TME.0000334370.14034.fc

24. Gordts B, Vrijens F, Hulstaert F, Devriese S, van de Sande S. The 2007 Belgian national prevalence survey for hospital acquired infections. Journal of Hospital Infection 2010; 163-167. https://doi.org/10.1016/j.jhin.2010.01.006

25. Morgan DJ, Rogawski E, Thom KA, Johnson JK, Perencevich EN, Shardell M, Leekha S, Harris AD. Transfer of multidrugresistant bacteria to healthcare workers' gloves and gowns after patient contact increases with environmental contamination. Crit Care Med 2012;40(4):1045-51.

https://doi.org/10.1097/CCM.0b013e31823bc7c8

26. Johnson E, Giri P, Parsons HK. Role of occupational health staff in investigation of invasive group A streptococcal infection hospital outbreak. J Hosp Infect 2012;81(3):199-201 https://doi.org/10.1016/j.jhin.2012.04.016

27. Humpreys H, Grundmann H, Skov R, Lucet JC, Cauda R. Prevention and control of methicillin resistant staphylococcus aureus. Clinical Microbiology and Infection 2009;2(15):120-124 https://doi.org/10.1111/j.1469-0691.2009.02699.x

28. Bagdonaitė R., Valintèlienė R., Macijauskienė A. ir kt. Meticilinui atsparaus Staphylococcus aureus valdymo būklè Lietuvos ligoninèse. Visuomenès sveikata, 2009; 3(46):107-114.

29. Arrowsmith VA, Taylor R. Removal of nail polish and finger rings to prevent surgical infection. Cochrane Database Syst Rev 2014;4;8:CD003325.

30. Mangram Aj, Horan TC, Pearson ML, Silver LC, Jarvis WR. The Hospital Infection Control Practice Advisory Committee: guideline for prevention of surgical site infection. Infect Control Hosp Epidemiol 1999; 20:247-280.

https://doi.org/10.1086/501620

31. Markevičè R. Tinkama rankų higiena - svarbu, suprantama, bet ar visada laikomés?. Slauga. Mokslas ir praktika, 2014; 2(206).

32. Tai JW, Mok ES, Ching PT, Seto WH, Pittet D. Nurses and physicians' perceptions of the importance and impact of healthcare-associated infections and hand hygiene: a multi center exploratory study in Hong Kong. Infection 2009;37(4):320-33. https://doi.org/10.1007/s15010-009-8245-x

33. Pittet D, Simon A, Hugonnet S, Pessoa-Silva CL, Sauvan V, Perneger TV. Hand hygiene among physicians: performance, beliefs, and perceptions. Ann Intern Med 2004;141(1):1-8 https://doi.org/10.7326/0003-4819-141-1-200407060-00008

34. Kerševičiūtė J. Medicinos personalo žinių, apie rankų higienos reikalavimų laikymąsi asmens sveikatos priežiūros įstaigose. Magistro baigiamasis darbas. Lietuvos sveikatos mokslų universitetas, Medicinos akademija, Visuomenès sveikatos fakultetas, Aplinkos ir darbo medicinos katedra. Kaunas, $2012 \mathrm{~m}$. Prieiga: file:///C:/Users/m.lamanauskaite/Desktop/rankos\%20 straipnis/2197068.pdf

35. Erasmus V, Brouwer W, van Beeck EF, Oenema A, Daha TJ, Richardus JH, Vos MC, Brug J. A qualitative exploration of reasons for poor hand hygiene among hospital workers: lack of positive role models and of convincing evidence that hand hygiene prevents cross-infection. Infect Control Hosp Epidemiol 2009;30(5):415-9.

https://doi.org/10.1086/596773

36. Jang JH, Wu S, Kirzner D, Moore C, Youssef G, Tong A, Lourenco J, et al. Focus group study of hand hygiene practice among healthcare workers in a teaching hospital in Toronto, Canada. Infect Control Hosp Epidemiol 2010;31(2):144-50. https://doi.org/10.1086/649792

37. Pittet D, Mourouga P, Perneger TV. Compliance with handwashing in a teaching hospital. Annals of Internal Medicine 1999; 130:126-130. https://doi.org/10.7326/0003-4819-130-2-199901190-00006

38. Barsanti MC, Woeltje KF. Infection prevention in the intensive care unit. Infectious disease clinics of North America 2009; 23: 703-25.

https://doi.org/10.1016/j.idc.2009.04.012

39. Friedman C, Newsom SWB, editors. IFIC Basic Concepts of Infection Control. 3rd ed. Portadown: International Federation of Infection Control 2007; 11-18.

\section{THE EVALUATION OF HAND HYGIENE} KNOWLEDGES OF HEALTH CARE WORKERS IN HEALTH CARE INSTITUTION

\section{Lamanauskaitė, J. Kairys, R. Šturienė}

Key words: healthcare - associated infections, healthcare - associated infections risk factors, hand hygiene, prevention measures. Summary

The aim of study - to evaluate medical staff knowledge about 
health care associated infections and hand hygiene among medical staff in public institution Šeškinès Clinic.

It was carried out medical staff questionnaire survey. The Questionnaire consisted of questions on healthcare - associated infections, healthcare - associated infections risk factors, hand hygiene and methods. 305 questionnaires were distributed and 255 was collected (response rate 83.6 percent.), the 245 were used in the study.

69.0 percent of respondents correctly identified healthcare - associated infections. The results of the study showed that respondents under the age of 40, having a 1.91 times higher chance of correctly understanding healthcare - associated infections than respondents aged over 41 years. The results of the study showed that respondents under the age of 40 with a 3.26 times higher chance of correctly understanding about pathways for the spread of pathogens than those who were older than 41 years of age. 20 percent of the respondents indicated that the pathogens of healthcare - asso- ciated infections did not spread through the hands. 64.5 percent of respondents have sufficient knowledge of healthcare - associated infections issues. It has been established that as much work experience as possible, the respondent has less knowledge about healthcare - associated infections $(r=-0.190 ; p=0.003) .41 .2$ percent of respondents indicated that medical staff sometimes do not carry out hand hygiene due to the use of skin irritants, $21.2 \%$. of respondents - due to a tight schedule. The results of the study showed that general practitioners, with a 2.46 times higher chance, indicated that the main reason for not doing hand hygiene was a tight schedule compared with other medical staff.

Correspondece to: relia@smc.1t

Gauta 2017-11-06 